\title{
Age-related changes in haematologic parameters of cage-raised Japanese quails (Cortunix japonica)
}

\begin{abstract}
Oluwasanmi Olayinka Aina ${ }^{1}$ and Temitayo Ajibade $^{2 *}$
${ }^{1}$ Department of Veterinary Anatomy, University of Ibadan, Oyo State, Nigeria.

${ }^{2}$ Department of Veterinary Physiology, Biochemistry and Pharmacology, University of Ibadan, Oyo State, Nigeria.

Received 16 December, 2014; Accepted 25 February, 2014

Blood samples were collected from clinically normal, cage-raised Japanese quails at regular intervals, over a six-week period. Full routine haematological analyses were carried out to establish reference values for growing individuals of this species and to assess age-related changes. The results of this study showed an initial significant reduction $(p<0.001)$ in the values of the mean corpuscular volume (MCV) and mean corpuscular haemoglobin (MCH) at the second week of age relative to the values at the first week of age. However, MCV values significantly increased $(p<0.001)$ weekly, up to the sixth week of age. Similarly, significant decrease $(p<0.05)$ was observed in the total white blood cell count at the second week of age, but subsequently remains unaltered throughout the period of the experiment. However, the heterophil:lymphocyte ratio increased significantly $(p<0.05)$ with increase in the age of birds. The observations in this study compares favourably with published literature.
\end{abstract}

Key words: Quails, haematology, age.

\section{INTRODUCTION}

The Japanese quail, Cortunix japonica, belongs to the family Phasidae and the genus Cortunix (Mizutani, 2003). The bird originally domesticated around the 11th century as a pet song bird, is now highly valued as a food animal in several parts of the world, because it constitutes an important source of eggs and meat (Kayang et al., 2004). In addition, the relatively short life span of $C$. japonica (3 to 4 generations per year) is a useful experimental tool with which to study the effect of age, nutrition, disease and environment on haematological parameters of birds (Ottinger, 2001; Holmes et al., 2003).

Haematology offers a valuable contribution in the veterinary care of avian species in providing differential diagnosis of pathological conditions and in monitoring responses to disease (Campbell, 1994). Moreover, the evaluation of haematological parameters is important clinically for analyzing the health status of farmed animals animals, providing reliable information on metabolic disorders, nutrient deficiencies and chronic stress status (Bahmani et al., 2001). Consequently, measuring and comparing haematological values with known standards is among the methods which contribute to the detection of some changes in the health status of avian species (Gavett and Wakeley, 1986). Unfortunately, these haematological values are influenced by various factors including breed, sex, age, reproductive status, exercise, circadian rhythm, handling procedure, degree of excitement and nutritional status of animals (Kramer, 2000).

Unlike most mammalian species for which information for haematological parameters abound, the reports on the baseline haematological values in birds and the various factors affecting these values are few. Some of the

*C orrespond ing author. E-mail: toajiba de@gma il.com. Tel: +2347032936615.

Author(s) agree that this artic le rema in pemanently open access under the terms of the $\underline{C}$ reative Commons Attribution License 4.0 Intemational License 
available reports include the reports of Torgowski and Kontecka (1998) on the blood cell count of pheasants; that of Vahala and Kase (1993) on age-and sex-related differences in haematological values of captive whitetailed gnu (Connochaetes gnou); and that of Olayemi et al. (2006) on haematological and plasma biochemical parameters of the Nigerian laughing dove (Streptopelia senegalensis), and the Nigerian duck (Anas platyrhynchos). Similarly, Gildersleeve et al. (1985) reported the haematological response of the Japanese quail to haemorrhagic stress. McCue et al. (2013) reported that targeted $13 \mathrm{C}$ enrichment of lipid and protein pools in the body reveals circadian changes in oxidative fuel mixture during prolonged fasting, suggesting alteration in plasma metabolite of the Japanese quail following a 6-day fasting period. Overall, there is a dearth of information on the physiological variations of haematological parameters in birds. Specifically, apart from the work of Ayub et al. (2012), that reported the effect of age on the haematological and biochemical profile of Japanese quails raised under the litter system, data on age-related haematological variations of the Japanese quail, to our knowledge, are nonexistent. Therefore, it is prudent to evaluate the effect of age on the haematologic parameters of the Japanese quail under experimental conditions to provide baseline information about the physiological status of these birds.

The purpose of this study was to observe haematological values in growing Japanese quail chicks up to the age of 6 weeks in order to establish reference values, determine any significant age-related changes and present analysis of the dynamics of changes in haematological values with age.

\section{MATERIALS AND METHODS}

\section{Experimental animals}

Sixty unsexed Japanese quails were obtained at one day of age from a local hatchery. The birds were kept at the brooder for three weeks and for another three weeks in metal cages with wire mesh doors and floors, measuring $80 \times 80 \times 40 \mathrm{~cm}$ at the ratio of 15 birds to one cage. Feed containing approximately $23 \%$ crude protein, 12.9 $\mathrm{MJ} / \mathrm{kg}$ metabolisable energy, with no medication and fresh clean water were provided ad libitum. Birds were kept in the dry season at room temperature $\left(27\right.$ to $\left.30^{\circ} \mathrm{C}\right)$ and relative humidity of about $70 \%$.

\section{Haematological analyses}

Blood samples were collected from birds, in the mornings between 0800 and $0900 \mathrm{~h}$, by wing venopuncture into sterile vials with $20 \mu \mathrm{l}$ of $10 \%$ ethylenediaminetetraacetic acid (EDTA), weekly for six weeks. Blood samples were quickly refrigerated at $4^{\circ} \mathrm{C}$ and analysed within $24 \mathrm{~h}$. Packed cell volume (PCV) and haemoglobin concentration $(\mathrm{Hb})$ were determined by the microhematocrit and cyanmethaemoglobin methods, respectively, as described by Jain (1986). Erythrocyte count was determined by the haematocytometry method as described by Jain (1986). Total white blood cell (WBC) counts were made in a haemocytometer using the WBC diluting fluid and differential leucocytes counts were made by counting the different types of WBC from Giemsa stained slides viewed (Coles, 1989). Erythrocyte indices including mean corpuscular volume (MCV), mean corpuscular haemoglobin (MCH) and mean corpuscular haemoglobin concentration $(\mathrm{MCHC})$ were determined from the values obtained from red blood cells (RBC) count, haemoglobin concentration and PCV values (Duncan et al., 1994).

MCV expresses the average volume of the individual RBC:

$\operatorname{MCV}(f l)=\frac{\operatorname{PCV}(\%) \times 10}{\operatorname{RBC}\left(10^{6} \mathrm{ul}^{-1}\right)}$

$\mathrm{MCH}$ expresses the average weight of hemoglobin $(\mathrm{Hb})$ in the erythrocyte:

$\mathrm{MCH}(\mathrm{Pg})=\frac{\mathrm{Hb}(\mathrm{g} / \mathrm{dl}) \times 10}{\operatorname{RBC}\left(\times 10^{6} \mathrm{ul}^{-1}\right)}$

MCHC gives the percentage of the MCV which the $\mathrm{Hb}$ occupies:

$\operatorname{MCHC}(g / d l)=\frac{H b(g / d l) \times 10}{\operatorname{PCV}(\%)}$

\section{Statistical analyses}

Statistical analyses were carried out by using graph pad PRISM software package (version 5.0). Statistical significance was assessed by the student t-test and the repeated measures analysis of variance (ANOVA). Results are presented as mean \pm standard error of mean, and value of probability less than $5 \%$ was considered statistically significant.

\section{RESULTS AND DISCUSSION}

The results for the age-related variations in haematological parameters of cage-raised Japanese quail are presented as shown in Table 1 and Figures 1 to 3 . All recorded haematological values are considered normal, because the birds remain clinically normal throughout the period of the experiment. However, the values of the MCV and $\mathrm{MCH}$ significantly decreased $(p<0.001)$ at the second week of age relative to the values at the first week of age (Figure 1). After the initial decrease, the value of the MCV significantly increased $(p<0.001)$ weekly, up to the sixth week of age (Figure 1). MCV measures the average size of individual red blood cells (Dacie et al., 1995). In most instances, a reduction in the value of MCV occurs when iron deficiency becomes severe and is a fairly specific indicator of iron deficiency once thalassemia and the anaemia of chronic disease have been excluded (Garby, 2002). The initial significant reduction in the values of $\mathrm{MCV}$, observed in this study may be due to accelerated erythropoiesis that significantly increases the demand for iron during haemoglobin formation. Accelerated erythopoiesis can also cause an increase in MCV values when iron is available in abundance, primarily due to the stimulatory effects of erythropoietin 
Table 1. Weekly haematological paarameters of cage-raised Japanese quail.

\begin{tabular}{lcccccc}
\hline Parameter & Week 1 & Week 2 & Week 3 & Week 4 & Week 5 & Week 6 \\
\hline PCV $(\%)$ & $30.01 \pm 3.13$ & $31.60 \pm 2.62$ & $31.62 \pm 1.14$ & $32.41 \pm 1.14$ & $31.82 \pm 2.58$ & $39.8 \pm 1.50$ \\
$\mathrm{Hb}(\mathrm{g} / \mathrm{dl})$ & $9.91 \pm 1.08$ & $10.51 \pm 0.85$ & $10.52 \pm 0.41$ & $10.74 \pm 0.36$ & $10.54 \pm 0.87$ & $13.18 \pm 0.45$ \\
$\mathrm{Rbc}\left(\times 10^{12} \mathrm{~L}^{-1}\right)$ & $2.28 \pm 0.64$ & $4.51 \pm 0.70$ & $4.80 \pm 1.60$ & $4.39 \pm 0.98$ & $3.62 \pm 0.81$ & $3.75 \pm 0.74$ \\
Wbc $\left(\times 10^{9} \mathrm{~L}^{-1}\right)$ & $8.01 \pm 1.38$ & $3.36 \pm 2.21$ & $14.21 \pm 3.41$ & $14.80 \pm 5.94$ & $10.88 \pm 0.81$ & $16.38 \pm 0.74$ \\
Platelet $\left(\times 10^{9} \mathrm{~L}^{-1}\right)$ & $8.87 \pm 0.81$ & $9.20 \pm 1.09$ & $9.72 \pm 0.38$ & $9.92 \pm 0.18$ & $9.62 \pm 0.89$ & $11.25 \pm 1.09$ \\
MCV $(\mathrm{fl})$ & $131.24 \pm 23.41$ & $71.42 \pm 12.50^{*}$ & $71.21 \pm 22.53^{* *}$ & $77.12 \pm 21.87^{* *}$ & $88.81 \pm 22.07^{* *}$ & $108.63 \pm 19.91^{* *}$ \\
MCH pg & $43.15 \pm 7.95$ & $21.77 \pm 4.02^{*}$ & $23.21 \pm 7.31$ & $25.21 \pm 7.15$ & $29.21 \pm 7.33$ & $35.81 \pm 6.26$ \\
MCHC $(\mathrm{g} / \mathrm{dl})$ & $33.18 \pm 0.89$ & $33.21 \pm 0.46$ & $33.09 \pm 0.45$ & $32.63 \pm 0.89$ & $33.41 \pm 1.14$ & $33.61 \pm 0.89$ \\
Lymphocyte $\left(\times 10^{9} \mathrm{~L}^{-1}\right)$ & $70.15 \pm 6.35$ & $62.41 \pm 4.35$ & $60.15 \pm 3.81$ & $58.41 \pm 3.78$ & $55.81 \pm 3.89$ & $54.21 \pm 3.49$ \\
Heterophil $\left(\times 10^{9} \mathrm{~L}^{-1}\right)$ & $29.10 \pm 5.76$ & $37.21 \pm 3.96$ & $39.21 \pm 3.96$ & $41.62 \pm 3.78$ & $44.11 \pm 4.18$ & $45.43 \pm 3.65$ \\
\hline
\end{tabular}

*Significant increase compared with week 1 ; ${ }^{* *}$ Significant increase compared with week 2.

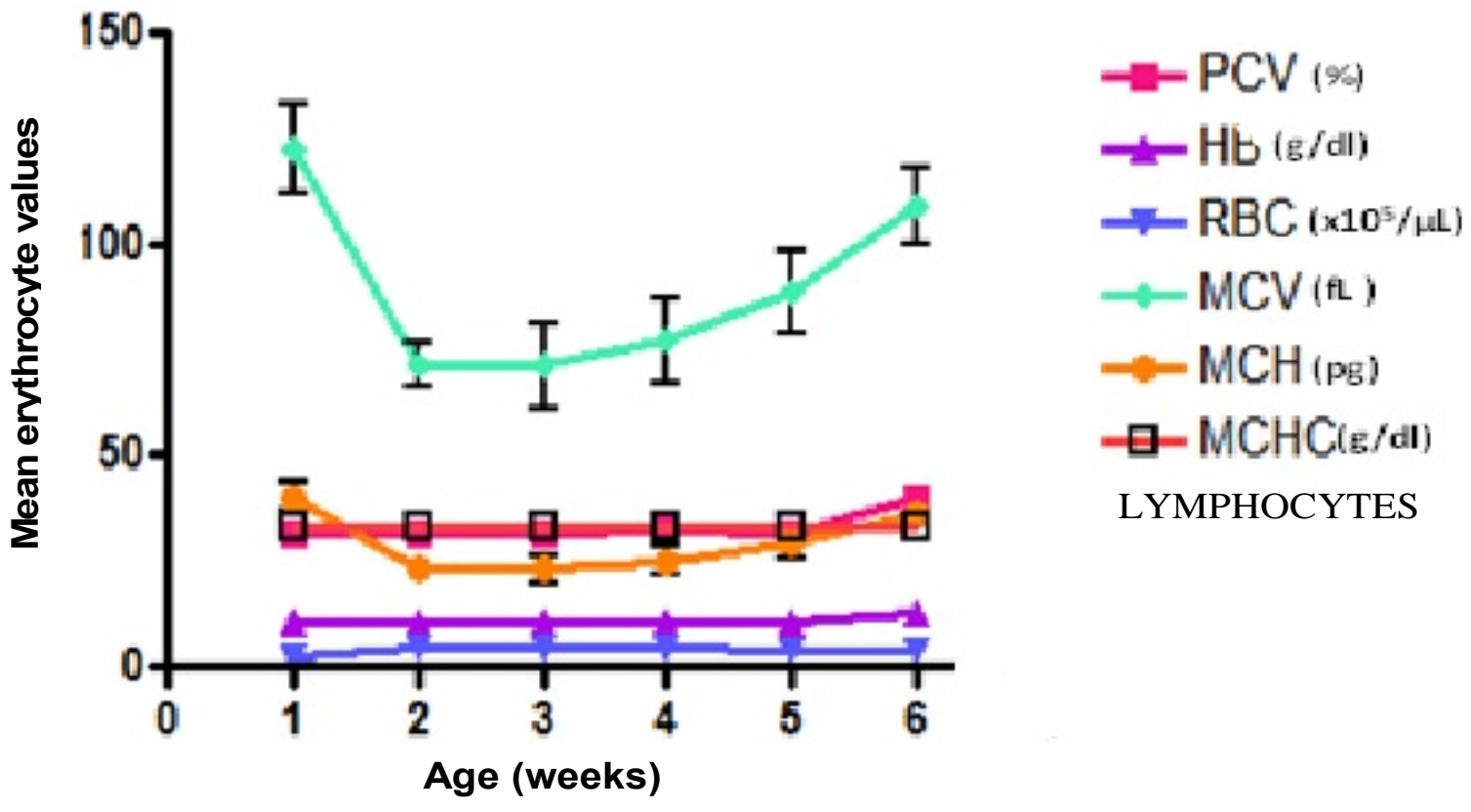

Figure 1. Mean weekly erythrocyte values of cage raised Japanese quail (Cortunix cortunix japonica). Asterisked values are calculated from the values of $\mathrm{PCV}, \mathrm{Hb}$ and $\mathrm{RBC}$.

on erythropoiesis. This is because erythropoietin causes the skipping of some non proliferative stages of erythopoiesis, leading to the release of large amount of reticulocytes into the circulation, and consequently increasing the MCV value. However, increase in MCV values due to accelerated erythropoiesis is usually preceded by acute and/or severe haemorrhagic or haemolyticanaemia, which is not the case in this study.

The decrease in MCV could have also resulted from changes in the relative proportions of erythrocyte type in bird embryos, compared to that of neonatal life. The larger primary erythrocytes which predominate in prenatal life decrease gradually during the second week, leaving predominantly mature erythrocytes, which may contribute to the gradual decrease in MCV. The subsequent gradual increase in the value of MCV is presumably due to the eventual predominance of mature erythrocytes in adulthood. In contrast to the age related variations in the values of $M C V$ and $\mathrm{MCH}$, variations observed in the values of the PCV, Hb, RBC and MCHC do not appear to be age related. This study agrees with the work of Ayub et al. (2012) who reported non-significant age-related variations in the values of PCV of Japanese quails raised under the litter system.

Also in this study, significant decrease $(p<0.05)$ was observed in the total white blood cell count at the second 


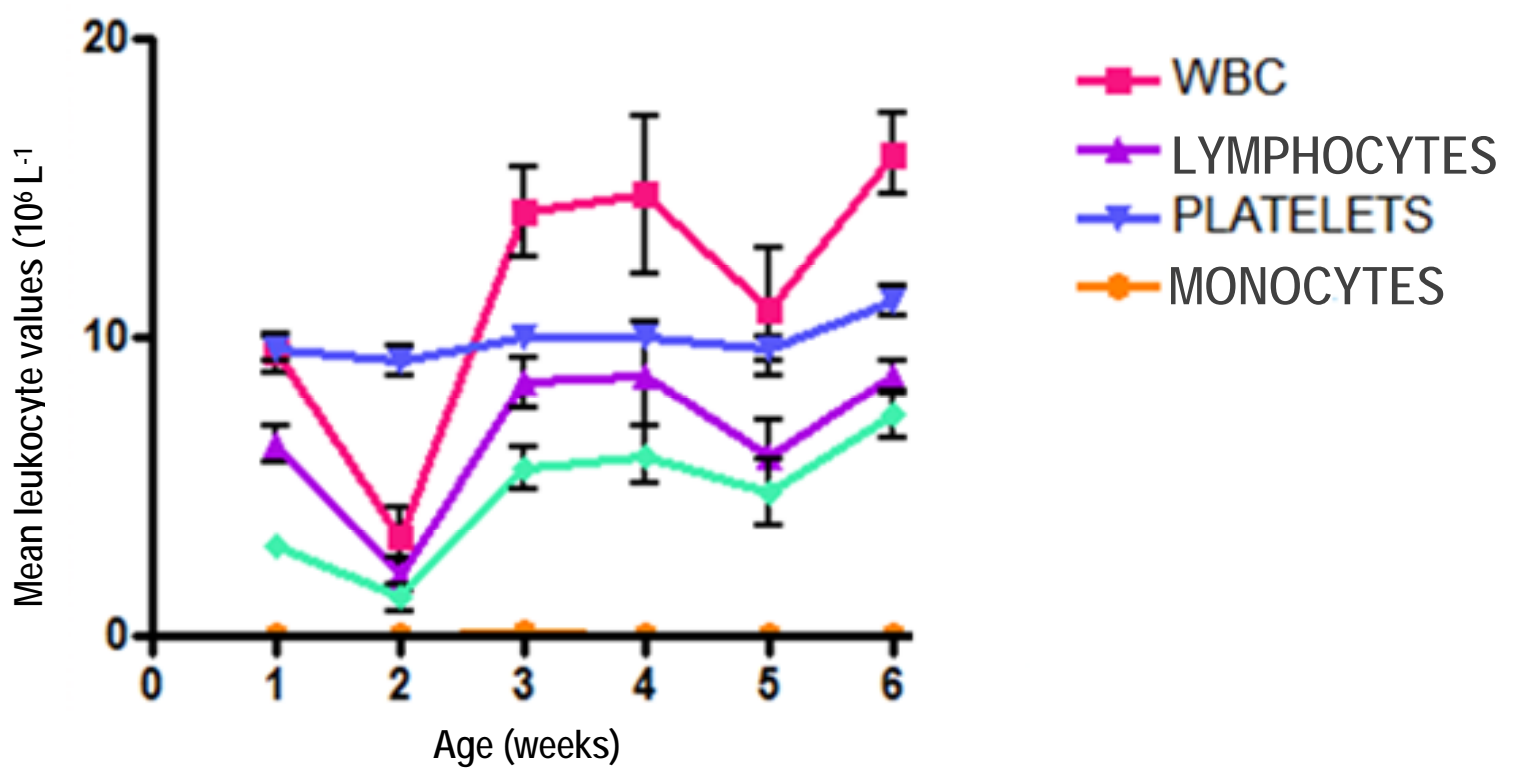

Figure 2. Mean weekly blood leukocyte values of cage raised Japanese quail (Cortunix cortunix japonica).

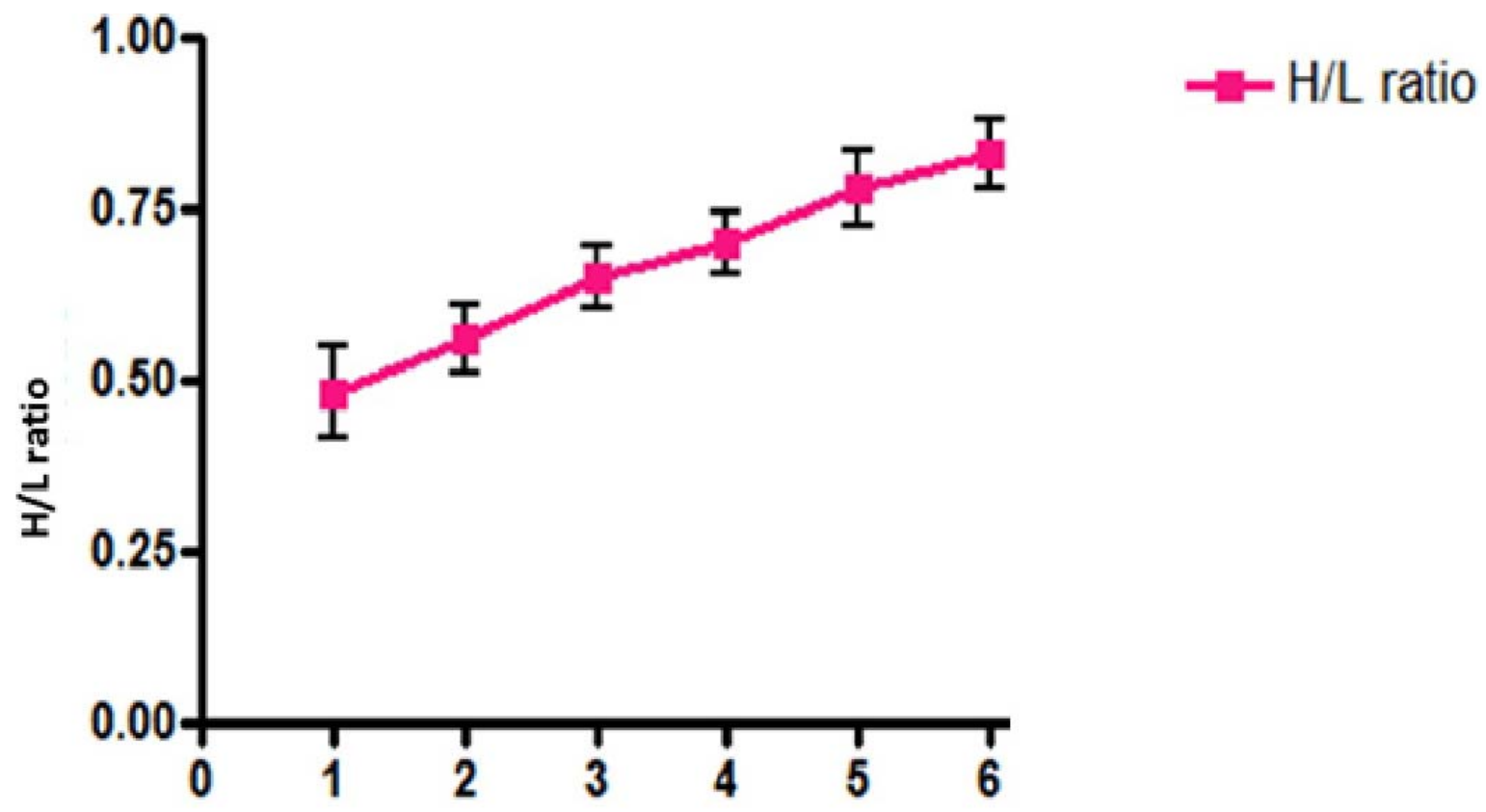

Age (weeks)

Figure 3. Mean weekly heterophil/lymphocyte ratio of cage raised Japanese quail (Cortunix cortunix japonica).

week of age, relative to the values recorded in the first week of age but subsequently remain unaltered throughout the period of the experiment (Figure 2). However, heterophil:lymphocyte ratio increased with increasing age of birds (Figure 3 ). This is similar to the results of Fouad et al. (2008) where a greater heterophil:lymphocyte ratios in caged chickens, compared to those reared in floor pens was observed.

The heterophil/lymphocyte ratio has been shown to be a reliable indicator of stress associated with injury, 
reproductive cycles and seasonal changes in birds in both captive and field situations (Moreno et al., 2002). Consequently, changes in this ratio have been used as indicators of stress response in domestic animals (Gross and Siegel, 1985). Birds normally have high numbers of circulating lymphocytes and may develop leukopenia and lymphopenia in the initial stress response (Ritchie et al., 1994). High numbers of circulating lymphocytes beyond the normal range might be physiologic, reactive, or proliferative (Jain, 1993). Transient physiologic lymphocytosis is observed with a marked release of epinephrine, because of physical or emotional stress (Aengwanich et al., 2003). In fact, epinephrine level increases within seconds of exposure to stress and glucocorticoids rise within minutes of stress exposure (Le Maho et al., 1992). Therefore, the increase heterophil:lymphocyte ratio observed in this study may indicate a physiologic response of the Japanese quail to the stress presented by confinement in cages. A number of stress factors, including water deprivation, temperature extremes and exposure to novel social conditions have been suggested to elevate the number of heterophils and depress the number of lymphocytes in birds (Gross 1989).

In conclusion, the observations in this study may aid understanding of haematological responses of the Japanese quail to different disease conditions, especially under intensive management. However, further studies of haematologic responses of this species to specific pathological conditions are required to further aid the management of disease condition of cage-raised Japanese quails.

\section{Conflict of Interests}

The author(s) have not declared any conflict of interests.

\section{REFERENCES}

Aengwanich W, Sridama $\mathrm{P}$, Phasuk $\mathrm{Y}$, Vongpralab T, Pakdee $\mathrm{P}$, Katawatin S, Simaraks S (2003). Effects of ascorbic acid on cell mediated, humoral immune response and pathophysiology of white blood cell in broilers under heat stress. Songklanakarin J. Sci. Technol. 25(3):297-305

Ayub Ali M, Hmar L, Inaotombi LD, Prava M, Lallianchhunga MC, Tolenkhomba TC (2012). Effect of age on the haematological and bio-chemical profile of Japanese quails (Coturnix japonica). Int. Multidiscp. Res. J. 2(8):32-35

Bahmani M, Kazemi R, Donskaya P (2001).A comparative study of some hematological features in young reared sturgeons (Acipenserpersicus and Husohuso). Fish Physiol. Biochem. 24:135140.

Campbell TW (1994). Hematology. In: Ritchie B.W., Harrison G.J., Harrison L.R. (Eds.): Avian Medicine: Principles and Application. Wingers Publishing, Inc., Lake Worth, Florida. pp 176-198.

Coles EH (1989). Veterinary Clinical Pathology, 3rd Edn., W.B. Saunders Company, Philadelphia. pp. 15-40.
Dacie JV, Lewis SM and Luzzatto L (1995). Laboratoratory methods used in the investigation of paroxysmal nocturnal haemoglobinuria (PHN). In: Dacie JV, Lewis SM (ed.), Practical haematology, 8th Ed. London: Churchill Livingstone. pp. 287-296).

Duncan JR, Prasse KW, Mahaffey EA (1994). Erythrocytes. In: Duncan JR, Prasse KW, Mahaffey EA (eds). Veterinary laboratory medicine. Clinical pathology. $3^{\text {rd }}$ Ed. lowa State University Press, Ames. 3-36

Fouad MA, Razek AHA, Badawy SM (2008).Broilers welfare and economics under two management alternatives on commercial scale. Int. J. Poult. Sci. 7:1167-1173.

Garby AJ (2002).Killing mechanisms of cytotoxic T. lymphocytes.News Physiol. Sci 2002; 13:17.

Gavett AP, Wakeley JS (1986).Blood constituents and their relationship to diet in urban and rural House Sparrows.Condor. 88:279-284.

Gildersleeve RP, Galvin MJ, Thaxton JP, Mcree DI (1985). Hematological responses of Japanese quail to acute hemorrhagic stress. Comp. Biochem. Physiol. 81:403-409.

Gross WB, Siegel PB (1985). Effect of Initial and Second Periods of Fasting on Heterophil/Lymphocyte Ratios and Body eight. Avian Dis. 30:345-346.

Gross WB (1989). Factors affecting chicken thrombocyte morphology and the relationship with heterophi1:lymphocyte ratios. Br. Poult. Sci. 30:919-925.

Holmes DJ, Thomson SL, Wu J, Ottinger MA (2003). Reproductive aging in female birds. Exp. Gerontol. 38 (7):751-756

Jain NC (1986). Schalm's Veterinary Haematology, 4th edn. Lea and Febiger, Philadelphia, USA, pp. 140-175.

Jain NC (1993). Essentials of Veterinary Hematology. 1st Ed. Philadelphia, USA: Lea and Febiger. pp. 295-306.

Kayang BB, Inoue-murayama VM, Miwa M, Monovoisin JL, Ito S, Minvielle F. (2004). A first generation micro satellite linkage map of the Japanese quail. Anim Gen. 35:195-200

Kramer JW (2000). Normal hematology of cattle, sheep and goats. In: Feldman BF, Zinkl JG, Jain NC (eds.), Schalm's Veterinary Hematology. 5th Ed. Philadelphia, USA: Lippincott Williams and Wilkins.

Le Mahoy YH, Karmannd D, Brioty Y, Handrich JP, Robin Y, Mioskowskyi E , Cherela ND, Farni J (1992). Stress in birds due to routine handling and a technique to avoid it. Am. J. Physiol. 263:775781.

McCue MD, Amaya JA, Yang AS, Erhardt EB, Wolf BO, Hanson DT (2013). "Targeted 13C enrichment of lipid and protein pools in the body reveals circadian changes in oxidative fuel mixture during prolonged fasting: a case study using Japanese quail." Compar. Biochem. Physiol. 166A: 546-554.

Mizutani M (2003). The Japanese quail. Laboratory Animal Research Station, Nippon Institute for Biological Science, Kobuchizawa, Yamanashi, Japan. P 408.

Moreno J, Merino S, Martinez J, Sanz JJ, Arriero E (2002).Heterophil/lymphocyte ratios and heat-shock protein levels are related to growth in nestling birds. Ecoscience. 9:434-439.

Olayemi FO, Ojo EA, Fagbohun OA (2006). Haematological and plasma biochemical parameters of the Nigerian Laughing dove (Anasplatyrhynchos). Vet. Arch. 76 (2):145-151.

Ottinger MA (2001). Quail and other short-lived birds. Exp. Ger. 36 (46):859-868.

Ritchie BW, Harrison GJ, Harrison LR (1994). Avian medicine: Principles and Application. Florida USA: Wingers Publishing, Inc. pp. 874-885.

Torgowski J, Kontecka H (1998). Effect of the addition of vitamin C and iron to pheasant (Phasianus colchicus) diets on their production and haematological indices. Zootechnika 50:235-242.

Vahala J, Kase F (1993). Age- and sex-related differences in haematological values of captive white gnu. Comp. Haematol. Int. 3:220-224. 